DOI https://doi.org/10.30525/978-9934-588-79-2-1.19

\title{
ДОСЛІДЖЕННЯ СЕМАНТИКИ ПРЕДМЕТНОЇ ОБЛАСТІ \\ МЕТОДІВ УПРАВЛІННЯ СКЛАДНИМИ СИСТЕМАМИ \\ В ГАЛУЗІ КОМП'ЮТЕРНИХ СИСТЕМ І МЕРЕЖ ЯК ВИЗНАЧАЛЬНОГО ЧИННИКА ЯКОСТІ П̈Ї ОПАНОВУВАННЯ НА ЗАСАДАХ КОМП'ЮТЕРНИХ ІНФОРМАЦІЙНИХ ТЕХНОЛОГІЙ
}

\author{
Соколова О. В. \\ кандидат технічних наук, \\ доиент кафедри інформаиійних технологій \\ Херсонського національного технічного університету \\ Веселовсыка Г. В. \\ кандидат технічних наук, дочент, \\ дочент кафедри інформачійних технологій \\ Херсонського національного технічного університету \\ м. Херсон, Украӥна
}

Розвиток науково-технічного прогресу обумовлює не тільки неперервне вдосконалювання довкілля людини, а й призводить до постійного суттєвого ускладнення систем, що є складовими частинами та знаряддями ії праці та побуту, а також управління зазначеними системами. Зокрема, особливо гостро дана проблема стосується сучасної комп'ютерної інженерії та, в іiї рамках, прогресивної галузі комп'ютерних систем і мереж (КСіМ).

У силу вищесказаного, викладання сучасних методів управління складними системами (МУСС) у галузі КСіМ, будучи високо актуальним, з однієї сторони, та маючи достатньо складну предметну область (ПрО) 3 інтенсивною динамікою розвитку, з іншого боку, потребує високоякісних підходів на основі інтенсивного залучення інтелектуалізованих комп'ютерних інформаційних технологій і посиленої уваги до дослідження семантики зазначеної ПрО під даним кутом зору.

А саме, в даному випадку, доцільним $є$ активне застосування інформаційних технологій експертних систем (ЕС) штучного інтелекту, що дозволяють спроектувати поле знань ПрО МУСС для галузі КСіМ, як навчальної дисципліни, на інформаційні простори інтегрованих систем баз знань, інтелектуалізованих інформаційно-пошукових і рекомендаційних систем, інтелектуальних агентів у мережі Internet тощо. 
Далі за текстом викладено результати аналізу та синтезу семантичної структури досліджуваної ПрО, що розглядається як предмет вивчення на засадах інтелектуалізованих комп'ютерних інформаційних технологій, де представлено ієрархію розбиття досліджуваної ПрО на лексико-семантичні поля (ЛСП) і лексико-семантичні групи (ЛСГ).

ЛСП «Основоположні поняття та теоретичні підходи щодо МУСС у галузі КСіМ» містить у своєму складі наведені нижче компоненти.

ЛСГ «Базові поняття про МУСС у галузі КСіМ» поєднує такі питання: визначення, ключові особливості, витоки появи, еволюція, перспективні напрямки розвитку, галузі застосування, концепції моделювання, специфіка апаратного та програмного інструментарію, особливості лінгвістичного й інформаційного забезпечення МУСС у контексті ПрО комп'ютерної інженерії, під кутом розгляду КСіМ як керуючих і керованих систем.

ЛСГ «Загальні підходи теорії нелінійного зворотного зв’язку та ковзаючих режимів у застосуванні до МУСС у галузі КСіМ» містить такі питання: базові поняття та методи теорії нелінійного зворотного зв'язку, зокрема, в управлінні складними системами з одним входом і виходом (SISO-системами), множинними входами та виходами (МІМО-системами) в галузі КСіМ; основоположні поняття, концепції, способи, підходи й інструментарій втілення теорії ковзаючих режимів у контексті МУСС у галузі КСіМ.

ЛСГ «Прикладні задачі систем із неперервним управлінням у застосуванні до МУСС у галузі КСіМ» передбачає такі питання: особливості, концепції та методи розв'язування типових прикладних задач систем із неперервним управлінням із застосуванням МУСС у галузі КСіМ.

ЛСП «Способи та підходи щодо оптимального оперативного управління функціонуванням складних систем у галузі КСіМ» містить наведені нижче компоненти.

ЛСГ «Характеристика складних систем як об’єктів проектування, реконструкції й оптимального оперативного управління. Математичне моделювання функціонування складних систем, для котрих проектується оптимальне оперативне управління, в галузі КСіМ» формується з таких питань: основні цілі, критерії й етапи проектування, реконструкції й оптимального оперативного управління складними системами в ПрО КСіМ. Базові поняття про математичні моделі функціонування складних систем, де проектується оптимальне оперативне управління, ідентифікацію їхньої структури та параметрів, оцінку їхньої адекватності, імітаційне моделювання технологічних процесів функціонування складних систем у галузі КСіМ. 
ЛСГ «Методи оптимального оперативного управління (ООУ) функціонуванням складних систем у галузі КСіМ» містить такі питання: структуризація задач ООУ функціонуванням складних систем, програмне управління технологічними процесами функціонування складних систем, методи й алгоритми розв'язування задач ООУ функціонуванням складних систем, оцінка ефективності та реалізація ООУ функціонуванням складних систем у галузі КСіМ.

ЛСП «Методи інтелектуалізації управління складними системами в галузі КСіМ» містить у своєму складі наведені нижче компоненти.

ЛСГ «Базові поняття про методи інтелектуального управління складними системами в галузі КСіМ» передбачає такі питання: постановка задачі управління в умовах недостатньої визначеності, повноти та достовірності інформації, галузі застосування та принципи побудови інтелектуального управління системами, основоположні поняття про методи інтелектуального управління складними системами на основі спеціалізованих підходів (евристичних, когнітивних, робастних тощо), концепцій синергетичного управління та парадигми гібридного інтелектуального управління в галузі КСіМ.

ЛСГ «МУСС на основі технологій нечіткої логіки в галузі КСіМ» формують такі питання: теоретичні основи управління складними системами на основі технологій нечіткої логіки (специфіка теорії нечітких множин; особливості нечіткого логічного виводу в управлінні динамічними об'єктами; правила нечіткого управління та нечіткі контролери; технічні та програмні засоби реалізації нечіткого управління; основи аналітичного конструювання регуляторів нечіткого управління, синтезу нечітких регуляторів на основі ймовірнісних моделей); базові способи та підходи до управління складними системами на основі технологій нечіткої логіки в галузі КСіМ.

ЛСГ «МУСС на основі технологій ЕС у галузі КСіМ» передбачає розгляд наступних питань: теоретичні основи управління складними системами на основі технологій ЕС (ключові поняття, формальні основи та класифікація ЕС; статичні та динамічні ЕС в управлінні; структура м'яких ЕС; методологія розробки ЕС; базові поняття про експертні регулятори для систем автоматичного управління динамічними об’єктами, адаптивні приводи та пристрої з експертними регуляторами; основні поняття про планування переміщень та управління рухом маніпуляційних роботів на основі технологій ЕС); основоположні способи та підходи щодо управління складними системами на основі технологій ЕС у галузі КСіМ.

ЛСГ «МУСС на основі технологій асоціативної пам'яті в галузі КСіМ» містить такі питання: теоретичні основи управління складни- 
ми системами на основі технологій асоціативної пам'яті (способи реалізації асоціативної пам'яті; особливості функціонування систем управління з асоціативною пам'яттю за умов невизначеності; специфіка управління рухом високоточних технологічних пристроїв, роботів на основі асоціативної пам'яті; адаптивне управління на базі асоціативної пам'яті; комбінування робастного й адаптивного управління засобами інтелектуальних систем; основні поняття про абсолютну стійкість систем управління пристроями з асоціативною пам'яттю); основоположні способи та прийоми управління складними системами на основі технологій асоціативної пам'яті в галузі КСіМ.

ЛСГ «МУСС на основі технологій нейромережних структур у галузі КСіМ» формується з таких питань: теоретичні основи управління складними системами на основі технологій нейромережних структур (особливості та класифікація штучних нейронних мереж; нейромережні регулятори для управління динамічними об'єктами; ідентифікація динамічних об'єктів на основі технологій нейронних мереж; генетичні алгоритми; інтелектуальні системи управління 3 експертнонейромережними регуляторами; самонавчальні системи управління на основі нейромережних структур); основоположні способи та підходи до управління складними системами на основі технологій нейромережних структур у галузі КСіМ.

У підсумку досліджень, було отримано наступні результати: обгрунтовано постановку й окреслено концепцію вирішення завдання дослідження семантики предметної області методів управління складними системами в галузі комп'ютерних систем і мереж, що розглядається в якості визначального фактора якості опановування зазначеної предметної області, на засадах інтелектуалізованих комп'ютерних інформаційних технологій, зокрема, експертних систем штучного інтелекту; результати аналітико-синтетичного формування семантичної структури досліджуваної предметної області, що розглядається як предмет вивчення на засадах інтелектуалізованих комп'ютерних інформаційних технологій, з отриманням ієрархічного розбиття досліджуваної предметної області на лексико-семантичні поля та групи.

\section{Література:}

1. Брусакова I. А. Основи теорії управління складними системами. Теоретична інноватика. Підручники для студентів онлайн, 2018. URL: https://stud.com.ua/114982/menedzhment/teoretichna_innovatika (дата звернення: 03.08.2020). 